\title{
Economic Performance and Competitiveness Indicators: The Case of African Economies
}

\author{
Vít Pošta1*, Marta Nečadová \\ ${ }^{1}$ Department of Economics and Management, University of Chemistry and Technology Prague, Technická 5, 16628 Praha 6, \\ Czech Republic \\ 2 Department of Managerial Economics, Faculty of Business Administration, Prague University of Economics and Business, \\ W. Churchill Sq. 1938/4, 13067 Prague 3 - Žižkov, Czech Republic \\ * Corresponding author, e-mail: vit.posta@vscht.cz
}

Received: 25 October 2019, Accepted: 10 March 2020, Published online: 13 May 2021

\begin{abstract}
This paper presents a statistical analysis of the relationship between economic performance and competitiveness indicators to address the question of the extent to which competitiveness indicators provideuseful information when assessing economic performance. The analysis was performed on various examples of African economies. The possible relationships between economic performance and competitiveness indicators were examined by extending a basic relationship between economic performance per capita and investment by competitiveness indicators. The models were estimated by means of an Arellano-Bond estimator. The authors detected many statistically significant relationships between economic performance and competitiveness indicators in the cases of both the whole sample and specifically middle-income economies. However, in the case of low-income economies there are no discernible relationships between economic performance and the information included in the competitiveness indicators. The paper contributes to the analysis of the economic performance of African economies, for which the empirical evaluation of possible links between economic performance and competitiveness indicators is altogether missing.
\end{abstract}

Keywords

African economies, competitiveness indicators, economic performance

\section{Introduction}

The regularly published competitiveness indicators represent potentially important information which constitutes part of the overall set of both economic and non-economic information on which the economic decision-making of individual agents and institutions is based. The aim of this paper is to evaluate to what degree, if any, the published data on national competitiveness by the World Economic Forum (WEF), probably the most well-known competitiveness indicators, is relevant in assessing the development of economic performance of African economies.

We choose African economies for two reasons. Firstly, as we show in the discussion of factors of economic growth below, African economies constitute a set of highly diversified countries as compared to the so-called advanced economies, the analysis of which has the potential for much broader conclusions to be drawn as to whether the value of information inherent in competitiveness indicators differs according to the level of economic performance. We show that it does, and that it does so in a significant way. Secondly, a quantitative analysis related to this question is missing.

We build our empirical analysis on the assessment of firstly, the existing and rather scarce evaluation of the relationship between the data on national competitiveness published by WEF and economic performance, which is contained in the first section of the paper, and secondly, the vast results regarding factors of economic growth, which is the subject of the second section.

The WEF competitiveness indicators promote the capture of especially microeconomic aspects of productivity and therefore, given the very basics of growth theory, it is expected that as such they should be related to the actual development of economic performance. However, the empirical evidence related to these questions is very scarce, especially sofar as less economically developed countries are concerned. On the other hand, there is a huge body of empirical assessment of the factors of economic 
growth, per se unrelated to the competitiveness indicators. We pay close attention to the results of this strand of research as it may help us to understand what may be hidden behind the statistical relationships that exist between economic performance and competitiveness indicators.

In the third section we present the data used in the empirical analysis, the various subsets of countries on which the analysis was performed, as well as the econometric approach taken. As we explain in that section, we employed an Arellano-Bond estimator. The fourth section of the paper states the results of the estimation and their assessment. The key findings are summarised in the final part of the paper, where we also relate the results back to both the first and second sections of the paper.

\section{WEF indicators of competitiveness and economic growth}

Our analysis is based on the indicators published by the World Economic Forum (WEF). However, we assume it is appropriate to introduce the concept of competitiveness from a broader perspective.

Buckley et al. (1988) summarise the relevant measures of international competitiveness. They recommend differentiating three dimensions: performance, potential, and management process, and four levels of analysis: country, industry, firm, and product. Delgado et al. (2012) emphasise three ideas connected with the evolution of the competitiveness debate: market share, costs, and productivity. High market share can be a symptom of underlying location advantages; however, the same result can be achieved through targeted and distortive subsidies as well. As they emphasise, the naive interpretation of competitiveness as low costs is misguided if prosperity is the policy's objective. Camagni (2002) also supports the territory approach to the assessment of competitiveness. Well-known objections to the term in question come from Krugman (1994; 1996), plus Cho and Moon (2005; 2013), who, generally speaking, consider the concept of macroeconomic competitiveness elusive and misleading, with Cho and Moon (2005; 2013) and Lall (2001) focusing especially on the well-known approach developed by Porter (1990).

Moving on to the concept of competitiveness on which we build our own technical analysis, Trabold (1995) and Berger and Bristow (2009) discuss four aspects of national competitiveness connected with the national level: the ability to sell (costs and trade performance), the ability to earn (productivity and performance orientation), the ability to adjust (innovation and flexibility), and the ability to attract (place attractiveness). Fagerberg et al. (2007) deem the same aspects of competitiveness necessary; they accept Krugman's critical remarks and seek relevant indicators for four factors of economic performance (technology competitiveness, capacity competitiveness, price competitiveness, and demand competitiveness) with a view to identifying the differences among them and overcoming the lack of a traditional approach, which focuses solely on price and cost comparisons. Their analysis based on statistical data can be reckoned to be the alternative to the traditional approach, which is primarily concerned with the potentially damaging effects of excessive wage growth on the economy.

All aspects of competitiveness mentioned above are taken into account in the most famous international competitiveness rankings (the World Competitiveness Yearbook, the Global Competitiveness report). These rankings point out the role of productivity and the capacities of countries to compete in world markets to improve their economic performance and standards of living. The final competitiveness indicator is constructed as a multidimensional composite indicator. The declared aim of composite indicators is to be a comprehensive evaluation of national competitiveness of a heterogeneous group of countries with different characteristics and on various stages of development. The fact of this heterogeneity has given rise to frequent critical objections to the methodology of these rankings. According to Cho and Moon $(2005 ; 2013)$ and Lall (2001), comparison of national competitiveness is more meaningful among the nations endowed with similar comparative advantages, situated on a similar level of development, and competing in similar industries.

The main pros and cons of using composite indicators have been widely debated. The discussion is summarised by Saisana and Tarantola (2002); the use of uncertainty and sensitivity analysis for gaining useful insights during the process of building composite indicators is recommended by Saisana et al. (2005). This methodology is accepted by Saltelli (2007), who, in the case of the Lisbon Strategy, explores the extent to which composite indicators are able to fulfil the task of underpinning the development of data-based narratives for political advocacy.

The Global Competitiveness Report (GCR) is published annually by the World Economic Forum (WEF). This annual competitiveness report is based mostly on soft data, which allows the monitoring of a larger number of countries than in the case of the World Competitiveness Yearbook. Global Competitiveness Index (GCI) for a given country is calculated as a weighted average of 12 pillars: institutions, infrastructure, macroeconomic environment, health and primary education, higher education and 
training, goods market efficiency, labour market efficiency, financial market development, technological readiness, market size, business sophistication, innovation. The first five pillars are referred to as basic requirements, the second five pillars are designated as efficiency enhancers and the last two pillars are known as innovation and sophistication factors. The weightings given to the pillars depend on the stage of development of the particular economy.

As Freudenberg (2003); Lall (2001); Ochel and Röhn (2006); Pérez-Moreno et al. (2016) point out, the choice of standardisation and normalisation method as well as the weighting given to the pillars has an impact on country rankings.

The results of checking the robustness of the WEF methodology were published in the Global Competitiveness Report (GCR) 2010-11. According to Nardo and Annoni (2010) the analysis confirms the GCI structure, but for some pillars, it suggests a redundancy in the subpillar division. Furthermore, some indicators were found to be statistically unrelated to the rest of indicators in respect of one pillar.

Berger and Bristow (2009); Lall (2001); Ochel and Röhn (2006) and others dispute these tests of the WEF report's robustness and focus on correlation instead of causation. They identify the problem of circular reasoning and causation. The also criticise the explanatory power of the econometric analysis applied by WEF (the GDP growth in the previous year versus the GCI or some components of GCI in the current year) with respect to the predictive ability of GCI.

From the perspective of the African economies the empirical evidence regarding the relationship between the WEF competitiveness indicators and economic performance is rather scarce. Some results may be found in the early Global Competitiveness Reports. In the case of low-income countries Porter (2004) identifies schooling, infrastructure, reduction of trade barriers and creation of financial markets as the key variables included in the competitiveness indicators so far as economic performance is concerned. This was confirmed later by Porter et al. (2006; 2007), the latter showing that the explanatory power of competitiveness indicators increases with the level of economic development of the countries.

\section{A review of factors of economic growth of African economies}

\subsection{The weakness of the growth theory}

There are some general obstacles to identifying key drivers of economic growth that should be taken to account. Ulaşan (2012) presents an informative review of econometric approaches to the identification of key factors of economic growth. He shows that, given the current strand of so-called new growth theories, the pool of possible growth determinants is virtually unlimited. Key limitations therefore come from the point of view of measurement and econometrical feasibility. This is well documented by Baştürk et al. (2012) who identify two different clusters in which the contribution of investment, real exchange rate distortions, trade openness, government share in GDP and investment price to GDP growth are significantly different. The first cluster regarding the sub-Saharan African countries includes: Botswana, Cameroon, Lesotho, Mauritius, Rwanda, Senegal, Togo and Zimbabwe and the second cluster includes: Gambia, Ghana, Kenya, Liberia, Malawi, Niger, Sierra Leone, South Africa, Sudan and Uganda. The most striking differences are: the effect of investment on economic growth is positive in both clusters, however, it is much stronger in the second cluster; the effect of trade openness on economic growth is positive in the first but negative in the second cluster; government share has a negative impact on economic growth in the first cluster but a positive one in the second cluster.

Moreover, Kenny and Williams (2001) argue that the failure of models of economic growth to produce replicable empirical results is linked to the fact that the origins and experiences of the respective economies with long-run economic development are highly heterogeneous. From the point of view of standard economic modelling, this means that the models are ahistorical, which significantly limits their explanatory and predictive power. Similarly, Lall (2001) points out that the WEF index has two key problems. It assumes that markets are efficient and that policy intervention must be "market friendly". This assumption discards the possibility of selective responses as a function of market failures, which, as he argues, may be all the more relevant in case of developing countries.

\subsection{Overview of the main factors of economic growth}

Mijiyawa's (2013) analysis shows that the key growth factors are: share of investment in GDP, private sector access to credit, government effectiveness and share of gross value added of agriculture in GDP. He performs a regression analysis between GDP growth and typical growth factors such as initial level of GDP per capita, population growth and share of investment in GDP, as well as share of population with completed primary education, private sector access to credit, quality of institutions, trade openness, 
share of value added of agriculture in GDP, inflation rate, urbanisation, and dummy for oil exporting countries.

The analysis of the World Bank (Chuhan-Pole et al., 2018) confirms these findings. It concludes that in 2017 the average growth of GDP accelerated especially due to improvements in terms of trade, higher metal production, improving conditions in agriculture and higher investment in physical capital. The key issues which represents an impediment to a more sustainable growth pattern seem to be linked to a weak infrastructure: electricity, water, sanitation, telecommunications and transport. As regards infrastructure, Calderón and Servén (2010) find that infrastructure has a positive impact on economic growth and negative impact on income inequality. They conclude the results hold true for African as well as other economies. More importantly, so far as the quality of infrastructure is concerned, they estimate that the costs for the African economies to catch up with other regions of similar income level would amount to investment as large as 15 percent of GDP.

An interesting result regarding labour productivity comes from Harrison et al. (2014) who performed an analysis using World Bank's Enterprise Surveys in 80 countries (32 sub-Saharan countries) with total of 12000 firms with the aim to compare the differences in labour productivity between non-rich African economies and the rest of the world. They show that the differences in labour productivity are explained by differences in geography (population), infrastructure, political institutions, business environment and financial conditions. Controlling for the effects of these variables they show that firms in non-rich African countries have in fact a comparative advantage in respect of to labour productivity, reaching higher levels of productivity as compared with the rest of the world.

However, as far as financial markets are concerned, Misati and Nyamongo (2012) demonstrate that financial liberalisation has tended to amplify the negative effect of inflation on economic growth. Thus, they recommend a managed financial openness as opposed to total liberalisation.

Beny and Cook (2009) confirm that from 1995 onwards the growth of African economies has been driven by institutional and policy reforms, exports of primary resources, and improving terms of trade.

Danquah and Quattara (2014) meanwhile show that there has been no convergence in technical efficiency levels among sub-Saharan economies. They show that the key drivers of technical efficiency were trade openness, stock of imported RD and machinery and the quality of institutions. On the other hand, they found the human capital factor to be insignificant. The findings of Jamison et al. (2007) show that the importance of human capital (quality of education) is more significant in an economic environment that is open to outside trade and influence. Badunenko et al. (2010) shows that the role of human capital is conditioned by the level of development. They demonstrate that the key sources of productivity growth are physical and human capital. The accumulation of physical capital was a much more important factor of productivity growth in poorer countries while the accumulation of human capital in the richer ones.

\subsection{Some specific issues of economic growth of African economies}

\subsubsection{Institutions}

As the research shows the idea of free markets as a solution to all economic problems should be discarded. Once more turning to Lall (1999; 2001), he points out the necessity of specific approach in the process of the choice of suitable macroeconomic policies in the developing countries. Free markets themselves cannot lead countries to develop the systemic abilities they need to cope efficiently with new technologies. Rapid liberalisation in sub-Saharan Africa has led to massive destruction of industrial capacity because the conditions needed for technological upgrading had not been laid down. Lall (1999) shows that government interventions are not necessarily distorting - on the contrary, policies to remedy market failures are legitimate factors deciding comparative advantage. The importance of institutions is well documented by Bertocchi and Guerzoni (2012) who examine the sources of fragility of sub-Saharan economies. They rely on the concept of fragility as defined by the Country Policy and Institutional Assessment ratings compiled by the World Bank. The sample consists of 41 sub-Saharan economies and the sample period runs from 1992 to 2007. The key factor of fragility identified by the estimations was institutional stability with other factors, including economic variables, having much lesser role or being insignificant altogether.

The analysis of Asongu and Kodila-Tedika (2016) confirms the necessity of respecting the specificities of sub-Saharan African countries in the process of macroeconomic decisions. Sub-Saharan Africa is one of the regions in the world that reflects characteristics of state fragility: weak governments, insufficient security and legal frameworks, ineffective administration, poor public services, high rates of conflicts and civil wars, and growing extreme poverty. 
Asongu and Kodila-Tedika (2016) test the hypothesis that state fragility is a function of rent seeking and/or lobbying by power holders. The resulting finding of great interest is the following: political interference, rent seeking and lobbying increase the probability of state fragility by mitigating the effectiveness of governance capacity. The validity of the hypothesis was confirmed in a scenario of extreme state fragility. Blanket fragility-oriented policies will be misplaced unless they are contingent on the degree of fragility, since fragile and extremely fragile countries respond differently to economic, institutional and demographic characteristics of state fragility.

Closely linked to the quality of institutions is the question of corruption, which in fact does not need to have strictly negative consequences. An interesting result is presented by Blackburn and Forgues-Puccio (2009) who show that the effects of corruption depend on the extent to which bureaucrats coordinate their rent-seeking behaviour. Their analysis predicts that countries with organised corruption networks are likely to display lower levels of bribes, higher levels of research activity and higher rates of growth than countries with disorganised corruption arrangements.

In Mahagaonkar (2008) it is shown that corruption has a negative effect on product innovation and organisational innovation. Corruption does not affect process innovation while it facilitates marketing innovation. According to Mahaonkar's findings, corruption is more disruptive to innovative activities mainly due to imperfect financial markets, selection of wrong projects by officials due to adverse selection, deliberate delays, a decrease in investment, and an increase in the cost of corruption.

Ugur (2014) shows that the effect of corruption on per-capita GDP is more adverse when primary studies take averages of the corruption data over periods longer than 5 years, when they use data for low income countries only and when they are published journal papers rather than book chapters or working papers. The stronger negative effect associated with the time period over which corruption data is averaged indicates that corruption has more adverse effects on per-capita GDP in the longer run as opposed to the short run.

\subsubsection{Electrification}

One of the key issues related to infrastructure which was shown to be one of the major obstacles to economic growth of the region is electrification. Peters and Sievert (2015) alert to the specificity of African countries in evaluation of socio-economic effects of electrification. Their analysis shows that in rural Africa, where most of the non-electrified households live, demand is very low. According to their analysis, the low electricity consumption can be served by low-cost solar alternatives. The authors regard the lack of access to markets in the short run as much more important for the development of non-agricultural activities than electrification.

Neelsen and Peters (2011) evaluate impacts of electrification on micro-firm performance in Uganda. Both the quantitative and qualitative information indicate that the effects on firm performance measured by profits or employee's income are small. They find no evidence for an expansionary effect of electrification on firm profits or worker remuneration, but they find a positive indirect impact of electrification due to the overall expansive effect on local demand.

Analysis of Scott et al. (2014) concentrate on SME in low and middle-income countries and reach similar results. Pre-existing conditions such as location, access to finance, and management competence have a strong impact on how access to electricity affects SME. Electricity access seems to have a lower positive impact on productivity of micro enterprises. This may be partly due to the fact that such firms do not use electricity-dependent machinery and processes, and partly because they lack backup power capacity to cope with outages in case they increase their reliance on electricity-dependent processes.

\subsubsection{Natural resources}

The economic growth of many African economies is closely related to natural resources, a fact which brings about various specific issues. Perrings (2014) presents an extensive analysis of negative side effects of economic growth based on exploitation of natural assets. He points to the fact that most of the standard economic growth models do not take account of externalities caused by exploitation of natural assets.

Maswana and Farooki (2013) found evidence that insufficient imported technologies explain the occurrence of resource curse in the long run although natural resources still indicate short-run positive effects on economic growth. In their view, this opens up room for public policy to offset the negative effects on long-run growth.

The negative effects of economic growth based on natural resources may be higher than most of the studies indicate. Brückner (2010) shows that using a purchasing power parity adjusted measure (defined as natural 
resource exports in US dollars over PPP GDP) yields an economically much larger negative relationship between per capita GDP growth and natural resource dependence than what has been suggested by the nominal measure. Consistent with the rent-seeking literature, he shows that the resource curse is a symptom of societies characterised by high levels of corruption and sluggish checks on political decision-making.

The link between the effects of exploitation of natural resources and institutions was also brought up by van der Ploeg and Venables (2012). The reasons for a relatively fast depletion in the developing countries are connected with the scarcity of capital, volatility of natural resources prices, and the fragility of state governance. In countries with fragile states or who exhibit an inability to constrain wasteful spending the recommended option may be to keep natural resources in the ground until the political system improves. Cust (2017) also identifies the rate of fragility of state governance as the key aspect of the final impacts. Countries with relatively weak governance, such as a lack of constraints on executive power, run the elevated risk of various resource curse challenges.

The relationship between the effects of natural resources and institutions probably does not run one way only. Arezki and van der Ploeg (2007) provide new evidence for the impact of natural resource dependence on income per capita. They find a significant indirect effect of natural resources on institutions. The natural resource curse is particularly detrimental to economic performance in countries with a low degree of trade openness.

From a different perspective, Sarr et al. (2011) show that international lending to poorer dictatorial countries whose performance is based on natural assets typically leads to looting, an economic strategy undermining long-run economic development. The reason why financial institutions are willing to lend to such countries is a moral hazard problem in the form of not internalising the risks of default, believing falsely that the large amount of natural assets precludes default.

\subsubsection{Other environmental and historical factors}

Bolt and Bezemer (2009) refute the proposition put forward by Acemoglu et al. (2001) that the higher settler mortality lead to setting up a system of even more extractive institutions which undermined the perspective of longrun economic development. They show, first, that higher settler mortality in fact did not lead to a sparser density of European settlement and, second, the lower density of
European settlement did not lead to more extractive institutions. They show that the key drivers of economic growth in the former colonies are education, with expected positive effect, and the high occurrence of disease (malaria) with negative effect. The analysis of Bhattacharyya (2009) confirms that the spread of Malaria plays an important role in explaining the evolution of national savings used as a measure of economic development. Badunenko et al. (2010) show that geographical factors also play an important role when comparing northern African and sub-Saharan economies. Greater exposure to tropical diseases and rainfalls lowers the returns on foreign direct investment and increases transaction costs on trade.

Pointing to the above-mentioned Bolt and Bezemer(2009), from a broader historical point of view, the discussion of long-run economic development by Bertocchi (2011) reveals that one of the specific factors in African context is slavery, both export slavery and internal one. Especially, turning to Nunn (2008) she argues that there is a robust negative relationship between the number of exported slaves from 1400 to 1900 in a country (geographical area) and its current economic development. The mechanism through which it worked is supposed to lie in negative effects of past export of slavery on institutions including ethnic fractionalisation caused by warfare directly connected with acquiring slaves.

Another specific factor is fertility. Hafner and MayerFoulkes (2013) show a causal long-run relationship between high income, high human development and low fertility. In economically advanced economies, with the completed demographic transition, only changes in human development and income matter. In developing countries, fertility is negatively related to human development, but positively to income and trade.

\section{Data and econometric approach}

We follow up on many of the papers which we referred to in the previous section to set up a basic structure that relates economic performance on one hand to evolution of capital on the other hand. We employ data from the World Bank. The economic performance is measured by three variables: gross domestic product per capita in purchasing power parity referred to as GDP/capita, gross domestic product per person employed in purchasing power parity referred to as GDP/empl, and gross national income per capita in purchasing power parity referred to as GNI/capita. As we detail further below, the estimation will be performed on differenced data, which means that the development of the performance indicators includes information 
on the evolution of both output and population. We do not measure capital by fixed assets because such a series is available only at a frequency of five years. Therefore, we measure the role of capital as a ratio of gross capital formation and gross domestic product. This variable is referred to as investment.

This basic structure is extended by autoregression in the performance indicator and by the information included in the competitiveness indices published by WEF. Given the discussion above, we are particularly interested in the subindex of basic requirements denoted as GCIBR, in the subindex of efficiency enhancers denoted as GCIEE, and in the subindex of innovation and sophistication factors denoted as GCIIF.

In the Appendix (Table 5) summarises the statistical properties of these series expressed in logarithms. The sample starts in 2006 and ends in 2017. The sample of the actual estimations is reduced due the inclusion of lagged dependent variable and instruments. The sample of the actual estimations is indicated in Tables 1 and 2.
We test for the presence of unit roots by utilising the Breitung unit root tests. We suppose the following representation of the panel:

$\Delta y_{i, t}=\alpha y_{i, t-1}+\sum_{j=1}^{n_{i}} \beta_{i, j} \Delta y_{i, t-j}+\delta x_{i, t}+\varepsilon_{i, t}$,

where $y$ represents the endogenous variable, $x$ stands for exogenous variables, $\varepsilon$ represents errors, $i$ denotes cross-sections, $j=1 \ldots n_{i}$ signifies possible different lag orders for the cross-sections.

As well as another unit root test frequently used in panel analysis, the Levin-Lin-Chu test, the Breitung unit root test assumes a common unit root process across the cross-sections. From the point of view of Eq. (1) this means that the parameter $\alpha$ is not differentiated according to the cross-sections. This assumption is preferable in this case because the sample is not based on particularly long data series. In addition to this fact, the Breitung test is less computationally complex than the Levin-Lin-Chu test, which given the data limitations with respect to time

Table 1 African economies

\begin{tabular}{|c|c|c|c|c|c|c|c|c|c|}
\hline $\begin{array}{l}\text { Model } \\
\text { Dependent }\end{array}$ & GCIBR & $\begin{array}{c}\text { GCIEE } \\
\text { gdp/capita }\end{array}$ & GCIIF & GCIBR & $\begin{array}{l}\text { GCIEE } \\
\text { gdp/empl }\end{array}$ & GCIIF & GCIBR & $\begin{array}{c}\text { GCIEE } \\
\text { gni/capita }\end{array}$ & GCIIF \\
\hline Dep. (-1) & $0.90 * * *$ & $0.92 * * *$ & $0.91 * * *$ & $0.88 * * *$ & $0.88 * * *$ & $0.90 * * *$ & $0.92 * * *$ & $0.93 * * *$ & $0.93^{* * *}$ \\
\hline Investment & $0.06^{* * *}$ & $0.06^{* * *}$ & $0.06^{* * *}$ & $0.06^{* * *}$ & $0.05^{* * *}$ & $0.06^{* * *}$ & $0.07 * * *$ & $0.05^{* * *}$ & $0.06^{* * *}$ \\
\hline CI & $0.01 * * *$ & -0.01 & 0.00 & $0.03 * * *$ & $0.03^{* * *}$ & $0.03^{* * *}$ & $0.01 * *$ & -0.01 & $0.01 * * *$ \\
\hline J-statistic & 28.69 & 28.62 & $28 . \mathrm{X}$ & 28.42 & 28.91 & 26.66 & 27.62 & 25.65 & 26.86 \\
\hline $\operatorname{AR}(1)$ & $-2.43 * *$ & $-2.48 * *$ & $-2.46^{* *}$ & $-2.48 * *$ & $-2.39 * *$ & $-2.40 * *$ & $-3.33 * * *$ & $-2.79 * *$ & $-3.36^{* * *}$ \\
\hline $\operatorname{AR}(2)$ & -0.82 & -0.69 & -0.76 & -1.36 & -1.38 & -1.47 & -1.42 & -1.34 & -1.35 \\
\hline
\end{tabular}

Notes: African economies listed in Appendix (Table 6): no. of cross-section, 29, time sample, 2008:2017

The competitiveness indicators GCIBR, GCIEE and GCIIF, and the performance indicators gdp/capita, gdp/empl, and gni/capita are explained in Section 3. CI refers to the competitiveness indicator used as an explanatory variable in the particular regression; this is given by the indicator used to name each model. Instruments: dynamic one lag of competitiveness indicator. J-statistic refers to the test of the validity of over-identifying restrictions with the null of the restrictions being valid. AR(1) and AR(2) refer to m-statistic of autocorrelation test in residuals with the null of no autocorrelation. *,**,** means rejection of the null at $10 \%, 5 \%$, and $1 \%$ level of significance, respectively.

Table 2 Sub-Saharan economies

\begin{tabular}{|c|c|c|c|c|c|c|c|c|c|}
\hline $\begin{array}{l}\text { Model } \\
\text { Dependent }\end{array}$ & GCIBR & $\begin{array}{c}\text { GCIEE } \\
\text { gdp/capita }\end{array}$ & GCIIF & GCIBR & $\begin{array}{l}\text { GCIEE } \\
\text { gdp/empl }\end{array}$ & GCIIF & GCIBR & $\begin{array}{c}\text { GCIEE } \\
\text { gni/capita }\end{array}$ & GCIIF \\
\hline Dep. (-1) & $0.90 * * *$ & $0.90 * * *$ & $0.91 * * *$ & $0.84 * * *$ & $0.84 * * *$ & $0.88 * * *$ & $0.92 * * *$ & $0.93 * * *$ & $0.94 * * *$ \\
\hline Investment & $0.06^{* * *}$ & $0.06 * * *$ & $0.06^{* * *}$ & $0.06^{* * *}$ & $0.05 * * *$ & $0.06^{* * *}$ & $0.07 * * *$ & $0.05 * * *$ & $0.07 * * *$ \\
\hline $\mathrm{CI}$ & $0.03 * * *$ & 0.02 & 0.00 & $0.05 * * *$ & 0.04 & $0.02 * * *$ & $0.04 * * *$ & 0.02 & $0.01 * * *$ \\
\hline J-statistic & 23.19 & 23.16 & 22.45 & 24.75 & 24.29 & 21.12 & 23.33 & 22.35 & 22.56 \\
\hline $\operatorname{AR}(1)$ & $-2.34 * *$ & -0.36 & $-2.37 * *$ & $-2.31 * *$ & $-2.20 * *$ & $-2.22 * *$ & $-2.82 * *$ & -0.01 & $-3.15^{* * *}$ \\
\hline $\operatorname{AR}(2)$ & -1.07 & -0.16 & -0.88 & $-1.98 * *$ & $-1.85^{*}$ & -1.70 & -1.60 & -1.57 & -1.50 \\
\hline
\end{tabular}

Notes: Sub-Saharan economies listed in Appendix (Table 7): no. of cross-section, 25, time sample, 2008:2017

The competitiveness indicators GCIBR, GCIEE and GCIIF, and the performance indicators gdp/capita, gdp/empl, and gni/capita are explained in Section 3. CI refers to the competitiveness indicator used as an explanatory variable in the particular regression; this is given by the indicator used to name each model. Instruments: dynamic one lag of competitiveness indicator. J-statistic refers to the test of the validity of over-identifying restrictions with the null of the restrictions being valid. AR(1) and AR(2) refer to m-statistic of autocorrelation test in residuals with the null of no autocorrelation. *,**,*** means rejection of the null at $10 \%, 5 \%$, and $1 \%$ level of significance, respectively. 
makes it more convenient for the purpose of our analysis. The null hypothesis of the Breitung test is that $\alpha$ is equal to zero, which means that the data contain unit root process.

The results in Appendix (Table 5) show that none of the series was found stationary in levels while all of them are stationary in first differences.

We perform the empirical investigation on several sets of African economies. The broadest set includes all African economies with sufficient data and is presented in the Appendix (Table 6). The subset of this initial sample are sub-Saharan economies as listed in the Appendix (Table 7). Further, we perform the analysis on two subsets of sub-Saharan economies which we denote as being middle income and low-income economies. The economies designated as lower and upper middle income by WEF are joined in the subset of middle- income economies and are listed in the Appendix (Table 8). Finally, Appendix (Table 9) presents the subset of low- income economies.

The general structure of the empirical model we estimate is:

$y_{i, t}=c_{i}+\alpha y_{i, t-1}+\delta x_{i, t}+\varepsilon_{i, t}$,

where $c$ represents constants, $y$ contains economic performance indicator, $x$ contains investment and competitiveness indicator. Given the fact that $y_{t-1}$ and $c$ are positively correlated, OLS cannot be employed. Any transformation based on fixed or random effects approach does not solve the problem as it would contain positive correlation between the transformed error term and transformed lagged depended variable. Therefore, this type of model is typically dealt with in first differences:

$\Delta y_{i, t}=\alpha \Delta y_{i, t-1}+\delta \Delta x_{i, t}+\Delta \varepsilon_{i, t}$,

which have already been shown to be stationary, see Appendix (Table 5). The estimation of the transformation
(Eq. (3)) typically rests on generalised method of moments, GMM, which employs instrumental variables. We now summarise the approach taken in this analysis.

Given the structure of the empirical model (Eq. (2)) we have to account for possible endogeneity relationships, possible autocorrelation and fixed effects and also nonstationarity of the series, which is reported in Appendix (Table 5). Therefore, we resort to the Arellano-Bond estimator. We use dynamically one lag of the competitiveness indicator, GCIBR, GCIEE or GCIIF, as instruments. The validity of instruments was tested by a Sargan-Hansen $J$-test, which is reported in Tables 1 to 4 .

In the estimation we employ a two-step White weighting matrix, which is robust to panel-specific autocorrelation and heteroscedasticity. Autocorrelation in the residuals was tested by means of an Arellano-Bond test for the presence of autoregression in the residuals. Given the fact that the model is estimated in first differences, the ArellanoBond test for AR(1) shows possible autoregression in the first differences of the residuals. This is confirmed in many of the cases, and was also expected. The more important is the test for the $\mathrm{AR}(2)$ autoregression, which indicates whether or not there is autoregression in the levels of the residuals. These results are also reported in Tables 1 to 4 . The estimation was performed in Eviews.

The main drawback of working with instruments is that in practice, there are many sets of instruments which may be used to employ the GMM estimator. As the underlying, true, economic model is unknown and various known factors cannot be measured it is generally impossible to choose an optimal set of instruments.

\section{Analysis of the results}

Tables 1 and 2 summarise the results of the estimations performed on the whole set of African economies and

Table 3 Middle income sub-Saharan economies

\begin{tabular}{|c|c|c|c|c|c|c|c|c|c|}
\hline $\begin{array}{l}\text { Model } \\
\text { Dependent }\end{array}$ & GCIBR & $\begin{array}{c}\text { GCIEE } \\
\text { gdp/capita }\end{array}$ & GCIIF & GCIBR & $\begin{array}{l}\text { GCIEE } \\
\text { gdp/empl }\end{array}$ & GCIIF & GCIBR & $\begin{array}{c}\text { GCIEE } \\
\text { gni/capita }\end{array}$ & GCIIF \\
\hline Dep. $(-1)$ & $0.86 * * *$ & $0.87 * * *$ & $0.86^{* * *}$ & $0.71 * * *$ & $0.76^{* * *}$ & $0.74 * * *$ & $0.87 * * *$ & $0.94 * * *$ & $0.90 * * *$ \\
\hline Investment & $0.07 * * *$ & $0.07 * * *$ & $0.06^{* * *}$ & $0.07 * * *$ & $0.07^{* * *}$ & $0.07 * * *$ & $0.07 * * *$ & $0.08^{* * *}$ & $0.06^{* * *}$ \\
\hline CI & $0.03^{* * *}$ & 0.01 & $0.02 * * *$ & $0.06^{* * *}$ & $0.03 * * *$ & $0.05^{* * *}$ & -0.04 & -0.02 & 0.01 \\
\hline J-statistic & 10.95 & 7.92 & 10.21 & 9.29 & 8.35 & 9.58 & 9.18 & 10.41 & 9.63 \\
\hline $\operatorname{AR}(1)$ & -1.52 & -1.46 & -1.45 & -1.44 & -1.40 & -1.37 & -1.42 & $-2.26^{* *}$ & $-2.26^{* *}$ \\
\hline $\operatorname{AR}(2)$ & $-1.76^{*}$ & $-1.87 *$ & $-1.94 * *$ & $-2.14 * *$ & $-2.43 * *$ & $-2.49 * *$ & -0.02 & -0.29 & -0.33 \\
\hline
\end{tabular}

Notes: Sub-Saharan middle-income economies listed in Appendix (Table 8): no. of cross-section, 12, time sample, 2008:2017

The competitiveness indicators GCIBR, GCIEE and GCIIF, and the performance indicators gdp/capita, gdp/empl, and gni/capita are explained in Section 3. CI refers to the competitiveness indicator used as an explanatory variable in the particular regression; this is given by the indicator used to name each model. Instruments: dynamic one lag of competitiveness indicator. J-statistic refers to the test of the validity of over-identifying restrictions with the null of the restrictions being valid. AR(1) and AR(2) refer to m-statistic of autocorrelation test in residuals with the null of no autocorrelation. $* * *, * * *$ means rejection of the null at $10 \%, 5 \%$, and $1 \%$ level of significance, respectively. 
Table 4 Low income sub-Saharan economies

\begin{tabular}{|c|c|c|c|c|c|c|c|c|c|}
\hline $\begin{array}{l}\text { Model } \\
\text { Dependent }\end{array}$ & GCIBR & $\begin{array}{c}\text { GCIEE } \\
\text { gdp/capita }\end{array}$ & GCIIF & GCIBR & $\begin{array}{l}\text { GCIEE } \\
\text { gdp/empl }\end{array}$ & GCIIF & GCIBR & $\begin{array}{c}\text { GCIEE } \\
\text { gni/capita }\end{array}$ & GCIIF \\
\hline Dep. (-1) & $0.84 * * *$ & $0.90 * * *$ & $0.86 * * *$ & $0.82 * * *$ & $0.87 * * *$ & $0.82 * * *$ & $0.89 * * *$ & $0.86 * * *$ & $0.90 * * *$ \\
\hline Investment & $0.02 * * *$ & $0.03 * * *$ & $0.03 * * *$ & $0.02 * * *$ & $0.03 * * *$ & $0.04 * * *$ & $0.02 * * *$ & $0.01 * * *$ & $0.03 * * *$ \\
\hline CI & 0.00 & -0.00 & -0.00 & 0.01 & 0.02 & -0.01 & 0.01 & $0.07 * *$ & 0.05 \\
\hline J-statistic & 9.98 & 8.86 & 6.91 & 9.61 & 9.81 & 7.60 & 12.41 & 11.48 & 11.74 \\
\hline $\operatorname{AR}(1)$ & $-1.71 *$ & -1.00 & $-1.82 *$ & $-1.69 *$ & -0.75 & -0.46 & $-2.23 * *$ & $-1.97 *$ & $-2.43 * *$ \\
\hline $\operatorname{AR}(2)$ & 01.09 & 0.31 & 0.52 & -0.19 & -0.24 & 0.01 & -1.63 & -1.64 & -1.64 \\
\hline
\end{tabular}

Notes: Sub-Saharan low-income economies listed in Appendix (Table 9): no. of cross-section, 13, time sample, $2008: 2017$.

The competitiveness indicators GCIBR, GCIEE and GCIIF, and the performance indicators gdp/capita, gdp/empl, and gni/capita are explained in Section 3. CI refers to the competitiveness indicator used as an explanatory variable in the particular regression; this is given by the indicator used to name each model. Instruments: dynamic one lag of competitiveness indicator. J-statistic refers to the test of the validity of over-identifying restrictions with the null of the restrictions being valid. AR(1) and AR(2) refer to m-statistic of autocorrelation test in residuals with the null of no autocorrelation. *, **,** means rejection of the null at $10 \%, 5 \%$, and $1 \%$ level of significance, respectively.

on the subset of sub-Saharan economies, respectively. While the development of GDP per capita is determined by investment and its past evolution as expected we find no support for the role of the information included in either of the two subindices of the competitiveness index GCIEE and GCIIF. The only subindex which displays a significant impact on the economic development is the basic requirements subindex GCIBR. However, the picture changes when we measure the economic performance by GDP per person employed and GNI per capita. In both sets of countries, all African economies and sub-Saharan economies, we find evidence for a positive impact of the subindices of innovation and sophistication factors and of general requirements on economic performance and in the case of the broader set of African economies we also find evidence for a positive relationship between GDP per person employed and the subindex of efficiency enhancers.

When comparing the role of basic requirements, given the estimated coefficients, there is a slightly stronger role of basic requirements in sub-Saharan economies with GDP per person employed or GNI per capita as economic performance indicators in comparison with the sample of all African economies. This cannot be stated about the effect of the subindex of innovation and sophistication factors whose role seems to be, if statistically significant, quantitatively similar.

As far as the estimates for the role of investment are concerned, there are practically no differences in the estimates between the sample of all African economies and the sample of sub-Saharan economies. We find a slightly lower autoregression in case of GDP per person employed in the sample of sub-Saharan economies as compared to the sample of all African economies but this has little practical significance.
Overall the estimates show that especially factors like institutions, infrastructure, macroeconomic environment, health and primary education, higher education and training summarised by the subindex of basic requirements and the factors of business sophistication and innovation entering the subindex of innovation and sophistication play an important role. On the other hand, the effects of goods market efficiency, labour market efficiency, financial market development and technological readiness, factors which may be categorised under the subindex of efficiency enhancers, play a practically indiscernible role. This may be partly explained by the dubious role of financial markets in macroeconomic development as discussed in the paper by Misati and Nyamongo (2012).

Next, we turn to the middle and low-income sub-Saharan economies. The results for these two sets are given in Tables 3 and 4 .

In the case of the middle-income sub-Saharan economies and gross national income per capita as economic performance indicator we do not find support for any of the competitiveness subindices to be an explanatory factor of the economic development. However, there is some support especially for the basic requirements and business sophistication and innovation factors when we take GDP per capita or per person employed as indicators of economic performance. It needs to be noted, however, that there is some residual autocorrelation in each of those estimates.

Comparing the results with those for the sample of all sub-Saharan economies, the role of investment is a little higher. The impact of the basic requirements and business sophistication and innovation factors is also higher, but not in the case of GNI as measure of economic performance. The role of the competitiveness indicators is also higher 
than in the sample of all African economies, once again when GDP is used as measure of economic performance.

The fact that the results for gross national income as an economic performance indicator may be weaker with respect to the competitiveness indicators is not surprising. Gross national income is, among other factors, positively influenced by remittances, which make a significant part of national income in some of the sub-Saharan economies and, on the other hand, it is negatively influenced by outflow of returns on foreign investment in those economies which receive it.

We do not detect any statistically significant relationships between the economic performance and competitiveness indicators in the case of low-income economies.

All the econometric estimation shows that we can detect significant relationships especially between factors such as institutions, infrastructure, macroeconomic environment, health and primary education, higher education and training, business sophistication and innovation on one hand and economic performance on the other hand. These relationships are the strongest in case of middle-income sub-Saharan economies and GDP as measure of economic performance.

The results bear a resemblance to the conclusions presented by other researches in the previous decade, which we mentioned in the first section of the paper. Namely it is the key role of the factors summarised in the basic requirements subindex and the fact that statistically significant relationships were detected in the middle income and not in the case of low-income countries. However, due to the completely different data sets and methods used we are not able to directly compare these quantitative results with the estimates of these much older studies.

\section{Conclusion}

The analysis focused on the relationship between three subsets of the WEF competitiveness index, namely basic requirements, efficiency enhancers and innovation and sophistication factors, and economic performance. The relationship was tested on a sample of African economies and then various subsamples: sub-Saharan economies, middle income sub-Saharan economies and low-income sub-Saharan economies.

The empirical evaluation of this question was performed by extending a very basic relationship between the evolution of economic performance per capita and the development of investment and lagged value of economic performance by including the competitiveness subindices.

In the case of African economies as a whole we showed that, independent of the measure of economic performance, the basic requirements of the competitiveness indicator always yield relevant information in the assessment of economic performance. When gross domestic product per person employed or gross national income per capita are used as measures of economic performance, innovation and sophistication factors are also relevant to the explanation of the development of economic performance.

The results are qualitatively very similar in the case of sub-Saharan economies. When we focused on middle income sub-Saharan economies, we found that basic requirements and innovation and sophistication factors are relevant to the evolution of economic performance if it is measured by gross domestic product per capita or gross domestic product per person employed. Their influence on economic performance is on average higher than in the case of all African or all sub-Saharan economies. The relationship is lost when gross national income is used as a measure of economic performance. We did not detect any statistically significant relationships between competitiveness indicators and economic performance in the case of low-income countries.

Given the results coming from the overview of the growth literature focused on African economies, we can therefore confirm the key role of policies promoting education, especially primary and secondary, infrastructure, the quality of institutions, especially regarding corruption, and trade. However, it should be noted, following up on the discussion of the factors of growth, that some of the frequently mentioned policies, electrification being a good example, in fact do not need to lead to significant positive changes in economic performance, especially if implemented in an isolated manner without taking account of related investment that together with electrification might ultimately boost business performance.

The question of dismantling barriers to trade, which seems to be very important for promoting economic growth, is tightly related to the attitudes of the key business partners abroad who seem to continue preferring importation of raw materials or at best products with negligible value added with the aim of using it for further processing at home or third countries. The existence of severe both tariff and nontariff measures imposed on processed and manufactured production coming from Africa is documented by Verter (2017).

It has to be noted, however, that the linkages between the results of this study and results presented in the first and second sections of the paper are informal. Strictly 
speaking, the results should be interpreted only as statistical findings in the sense that they show in various cases support for positive relationship between economic performance and competitiveness, however, since the model is an empirical one, not a structural one, it cannot be explained what exactly lies behind the detected relationships. The discussion of the factors of economic growth shows that there are practically no conclusions that would hold for all the economies in question. While it is generally conceivable to formulate a model that would go deeper under the basic structure we used, which means linking economic performance to more specific factors behind the various sub-indices, the theoretical discussion

\section{References}

Acemoglu, D., Johnson, S., Robinson, J. A. (2001) "The Colonial Origins of Comparative Development: An Empirical Investigation", American Economic Review, 91(5), pp. 1369-1401. https://doi.org/10.1257/aer.91.5.1369

Arezki, R., van der Ploeg, F. (2007) "Can the Natural Resource Curse Be Turned Into a Blessing? The Role of Trade Policies and Institutions", International Monetary Fund, Washington, DC, USA, IMF Working Paper WP/07/55. https://doi.org/10.5089\%2F9781451866193.001

Asongu, S., Kodila-Tedika, O. (2016) "State Fragility, Rent Seeking and Lobbying: Evidence from African Data", International Journal of Social Economics, 43(10), pp. 1016-1030. https://doi.org/10.2139\%2Fssrn.2493357

Badunenko, O., Henderson, D. J., Houssa, R. (2010) "Explaining African Growth Performance: A Production-Frontier Approach", Center for Research in the Economics of Development, University of Namur, Namur, Belgium, CRED Working Paper 2010/13. https://doi.org/10.2139\%2Fssrn.1742471

Bhattacharyya, S. (2009) "Root Causes of African Underdevelopment", Journal of African Economies, 18(5), pp. 745-780. https://doi.org/10.1093\%2Fjae\%2Fejp009

Baştürk, N., Paap, R., van Dijk, D. (2012) "Structural differences in economic growth: an endogenous clustering approach", Applied Economics, 44(1), pp. 119-134. https://doi.org/10.1080/00036846.2010.500274

Beny, L. N., Cook, L. D. (2009) "Metals or Management? Explaining Africa's Recent Economic Growth Performance", American Economic Review, 99(2), pp. 268-274. https://doi.org/10.1257/aer.99.2.268

Berger, T., Bristow, G. (2009) "Competitiveness and the Benchmarking of Nations - A Critical Reflection", International Advances in Economic Research, 15(4), pp. 378-392. https://doi.org/10.1007\%2Fs11294-009-9231-x

Bertocchi, G. (2011) "Chapter 3 Growth, Colonization, and Institutional Development: In and Out of Africa", In: de La Grandville, O. (ed.) Economic, Growth and Development, Vol. 11, Emerald Group Publishing Limited, Bingley, UK, pp. 25-41. https://doi.org/10.1108\%2Fs1574-8715\%282011\%290000011008 shows that this would only be meaningful in the case of particular economies as a time-series analysis, not in the case of a sample of economies in the form of panel analysis. The problem is that such an analysis requires data with respect to time dimension, which is not available. The history of data on competitiveness is very limited for both more and less economically developed economies and in many cases of the latter group the same is true for the data on economic development.

\section{Acknowledgement}

The research related to this article did not receive any funding.

Bertocchi, G., Guerzoni, A. (2012) "Growth, History, or Institutions? What Explains State Fragility in Sub-Saharan Africa", Journal of Peace Research, 49(6), pp. 769-783. https://doi.org/10.1177\%2F0022343312452420

Blackburn, K., Forgues-Puccio, G. F. (2009) "Why is corruption less harmful in some countries than in others?", Journal of Economic Behavior \& Organization, 72(3), pp. 797-810. https://doi.org/10.1016\%2Fj.jebo.2009.08.009

Bolt, J., Bezemer, D. (2009) "Understanding Long-Run African Growth: Colonial Institutions or Colonial Education?", The Journal of Development Studies, 45(1), pp. 24-54. https://doi.org/10.1080\%2F00220380802468603

Brückner, M. (2010) "Natural resource dependence, non-tradables, and economic growth", Journal of Comparative Economics, 38(4), pp. 461-471. https://doi.org/10.1016\%2Fj.jce.2010.06.002

Buckley, P. J., Pass, Ch. L., Prescott, K. (1988) "Measurement of International competitiveness: A critical survey", Journal of Marketing Management, 4(2), pp. 175-200. https://doi.org/10.1080\%2F0267257x.1988.9964068

Calderón, C., Servén, L. (2010) "Infrastructure and Economic Development in Sub-Saharan Africa", Journal of African Economies, 19(Supplement 1), pp. i13-i87. https://doi.org/10.1093/jae/ejp022

Camagni, R. (2002) "On the Concept of Territorial Competitiveness: Sound or Misleading?", Urban Studies, 39(13), pp. 2395-2411. https://doi.org/10.1080\%2F0042098022000027022

Cho, D.-S., Moon, H.-C. (2005) "National Competitiveness: Implications for Different Groups and Strategies", International Journal of Global Business and Competitiveness, 1(1), pp. 1-11. [online] Available at: https://www.researchgate.net/publication/242577908_National_ Competitiveness_Implications_for_Different_Groups_and_ Strategies [Accessed: 20 June 2019]

Cho, D.-S., Moon, H.-C. (2013) "International Review of National Competitiveness. A Detailed Analysis of Sources and Rankings", Edward Elgar Publishing, Inc., Northampton, MA, USA. https://doi.org/10.4337\%2F9781782545583 
Chuhan-Pole, P., Calderon, C., Kambou, G., Blimpo, M., Korman, V. (2018) "Africa's Pulse: An Analysis of Issues Shaping Africa's Economic Future", Vol. 17, World Bank, Washington, D.C., USA. https://doi.org/10.1596/978-1-4648-1291-0

Cust, J. (2017) "The role of governance and international norms in managing natural resources", United Nations University World Institute for Development Economics Research (UNU-WIDER), Helsinki, Finland, WIDER Working Paper 2017/203. https://oi.org/10.35188/UNU-WIDER/2017/429-2

Danquah, M., Quattara, B. (2014) "What drives national efficiency in sub-Saharan Africa", Economic Modelling, 44, pp. 171-179. https://doi.org/10.1016\%2Fj.econmod.2014.10.019

Delgado, M., Ketels, C., Porter, M. E., Stern S. (2012) "The Determinants of National Competitiveness", National Bureau of Economic Research, Cambridge, MA, USA, Working Paper 18249. https://doi.org/10.3386\%2Fw18249

Fagerberg, J., Srholec, M., Knell, M. (2007) "The Competitiveness of Nations: Why Some Countries Prosper While Others Fall Behind", World Development, 35(10), pp. 1595-1620. https://doi.org/10.1016/j.worlddev.2007.01.004

Freudenberg, M. (2003) "Composite Indicators of Country Performance: A Critical Assessment", OECD Publishing, Paris, France, OECD Science, Technology and Industry Working Papers 2003/16. https://doi.org/10.1787\%2F405566708255

Hafner, K. A., Mayer-Foulkes, D. (2013) "Fertility, economic growth, and human development causal determinants of the developed lifestyle", Journal of Macroeconomics, 38(A), pp. 107-120. https://doi.org/10.1016\%2Fj.jmacro.2013.04.001

Harrison, A. E., Lin, J. Y., Xu, L. C. (2014) "Explaining Africa's (Dis)advantage", World Development, 63, pp. 59-77. https://doi.org/10.1016/j.worlddev.2013.10.011

Jamison, E. A., Jamison, D. T., Hanushek, E. A. (2007) "The effects of education quality on income growth and mortality decline", Economics of Education Review, 26(6), pp. 771-788. https://doi.org/10.1016/j.econedurev.2007.07.001

Kenny, C., Williams, D. (2001) "What Do We Know About Economic Growth? Or, Why Don't We Know Very Much?", World Development, 29(1), pp. 1-22. https://doi.org/10.1016/s0305-750x(00)00088-7

Krugman, P. (1994) "Competitiveness: A Dangerous Obsession", Foreign Affairs, 73(2), pp. 28-44. https://doi.org/10.2307/20045917

Krugman, P. R. (1996) "Making Sense of the Competitiveness Debate", Oxford Review of Economic Policy, 12(3), pp. 17-25. https://doi.org/10.1093\%2Foxrep\%2F12.3.17

Lall, S. (1999) "Competing with Labour: Skills and Competitiveness in Developing Countries", International Labour Organization, Geneva, Switzerland, Issues in Development Discussion Paper No. 31. [online] Available at: https://www.ilo.org/employment/ Whatwedo/Publications/WCMS_123613/lang--en/index.htm [Accessed: 19 June 2019]

Lall, S. (2001) "Competitiveness Indices and Developing Countries: An Economic Evaluation of the Global Competitiveness Report", World Development, 29(9), pp. 1501-1525. https://doi.org/10.1016\%2Fs0305-750x\%2801\%2900051-1
Mahagaonkar, P. (2008) "Corruption and Innovation: A Grease or Sand relationship?", Friedrich Schiller University Jena, Max Planck Institut of Economics, Jena, Germany, Jena Economic Research Papers 2018-017. [online] Available at: https://ideas.repec.org/p/ jrp/jrpwrp/2008-017.html [Accessed: 19 June 2019]

Maswana, J.-C., Farooki, M. (2013) "African Economic Growth Prospects: A Resource Curse Perspective", Applied Econometrics and International Development, 13(2), pp. 169-182. [online] Available at: https://i-deas.repec.org/a/eaa/aeinde/v13y2013i2_12. html [Accessed: 19 June 2019]

Mijiyawa, A. G. (2013) "Africa's Recent Economic Growth: What Are the Contributing Factors?", African Development Review, 23(3), pp. 289-302. https://doi.org/10.1111/j.1467-8268.2013.12030.x

Misati, R. N., Nyamongo, E. M. (2012) "Financial liberalization, financial fragility and economic growth in Sub-Saharan Africa", Journal of Financial Stability, 8(3), pp. 150-160. https://doi.org/10.1016\%2Fj.jfs.2011.02.001

Nardo, M., Annoni, P. (2010) "Appendix B: The Joint Research Centre assessment of the Global Competitiveness Index", In: Schwab, K. (ed.) The Global Competitiveness Report 2010-2011, World Economic Forum, Geneva,Switzerland, pp. 49-55. [online] Available at: http://www3.weforum.org/ docs/WEF_Glo-balComp etitivenessReport 2010-11.pdf [Accessed: 19 June 2019]

Neelsen, S., Peters, J. (2011) "Electricity usage in micro-enterprises Evidence from Lake Victoria, Uganda", Energy for Sustainable Development, 15(1), pp. 21-31. https://doi.org/10.1016\%2Fj.esd.2010.11.003

Nunn, N. (2008) "The Long-term Effects of Africa's Slave Trades", The Quarterly Journal of Economics, 123(1), pp. 139-176. https://doi.org/10.1162/qjec.2008.123.1.139

Pérez-Moreno, S., Rodríguez, B., Luque, M. (2016) "Assesing global competitiveness under multicriteria perspective", Economic Modelling, 53, pp. 398-408. https://doi.org/10.1016\%2Fj.econmod.2015.10.030

Ochel, W., Röhn, O. (2006) "Ranking of Countries - The WEF, IMD, Fraser and Heritage Indices", CESifo DICE Report, 4(2), pp. 48-60. [online] Available at: https://www.ifo.de/en/node/29090 [Accessed: 19 June 2019]

Perrings, C. (2014) "Environment and development economics 20 years on", Environmental and Development Economics, 19(3), pp. 333-366. https://doi.org/10.1017/s1355770x14000369

Peters, J., Sievert, M. (2015) "Impacts of Rural Electrification Revisited - The African Context", Rheinisch-Westfälisches Institut für Wirtschaftsforschung (RWI), Essen, Germany, Ruhr Economic Papers 556. https://doi.org/10.2139/ssrn.2618447

Porter, M. E. (1990) "The Competitive Advantage of Nations", Free Press, New York, NY, USA.

Porter, M. E. (2004) "Building the Microeconomic Foundations of Prosperity: Findings from the Business Competitiveness Index", In: Porter, M. E., Schwab, K., Sala-i-Martin, X. (eds.) The Global Competitiveness Report 2003-2004, Oxford University Press, New York, NY, USA, pp. 29-56. [online] Available at: https://www.hbs. edu/faculty/Publication\%20Files/BCI_Chapter_adf284c6-3d8b483e-9f29-a5242e9c5999.pdf [Accessed: 19 June 2019] 
Porter, M. E., Ketels, C., Delgado, M. (2006) "The Microeconomic Foundations of Prosperity: Findings from the Business Competitiveness Index", In: Lopez-Claros, A. (ed.) The Global Competitiveness Report 2006-2007, Palgrave Macmillan, Basingstoke, UK, pp. 51-80. [online] Available at: http://www3. weforum.org/docs/WEF_GlobalCompetitivenessReport_2006-07. pdf [Accessed: 19 June 2019]

Porter, M. E., Ketels, C., Delgado, M. (2007) "The Microeconomic Foundations of Prosperity: Findings from the Business Competitiveness Index", In: Porter, M., Sala-i-Martin, X., Schwab, K. (eds.) The Global Competitiveness Report 2007-2008, Palgrave Macmillan, Basingstoke, UK, pp. 51-81. [online] Available at: https://www.researchgate.net/publication/237254147_The_ Microeconomic_Foundations_of_Prosperity_Findings_from_ the_Business_Competitiveness_Index [Accessed: 19 June 2019]

Saisana, M., Tarantola, S. (2002) "State-of-the-art Report on Current Methodologies and Practices for Composite Indicator Development", European Commission, Joint Research Centre, Ispra, Italy, Rep. EUR 20408 EN. [online] Available at: https://www.eea.europa. eu/data-and-maps/indicators/economic-water-productivity-ofirrigated/state-of-the-art-report [Accessed: 19 June 2019]

Saisana, M., Saltelli, A., Tarantola, S. (2005) "Uncertainty and sensitivity analysis techniques as tools for the quality assessment of composite indicators", Journal of the Royal Statistical Society: Series A (Statistics in Society), 168(2), pp. 307-323. https://doi.org/10.1111\%2Fj.1467-985x.2005.00350.x

Saltelli, A. (2007) "Composite Indicators between Analysis and Advocacy", Social Indicators Research, 81(1), pp. 65-77. https://doi.org/10.1007\%2Fs11205-006-0024-9

Sarr, M., Bulte, E., Meissner, C., Swanson, T. (2011) "On the looting of nations", Public Choice, 148(3-4), pp. 353-380. https://doi.org/10.1007\%2Fs11127-010-9659-9
Scott, A., Darko, E., Lemma, A., Rud, J.-P. (2014) "How does electricity insecurity affect businesses in low and middle income countries?", ODI Report, Overseas Development Institute, London, UK. [online] Available at: https://www.odi.org/publications/9184-howdoes-electricity-insecurity-affect-businesses-low-and-middleincome-countries [Accessed: 19 June 2019]

Trabold, H. (1995) "Die internationale Wettbewerbsfähigkeit einer Volkswirtschaft" (The International Competitiveness of an Economy), Vierteljahrshefte zur Wirtschaftsforschung, 64(2), pp. 169-185. [online] Available at: https://www.diw.de/sixcms/detail. php?id=diw01.c.445392.de [Accessed: 19 June 2019] (in German)

Ugur, M. (2014) "Corruption's Direct Effects on per-capita Income Growth: A Meta-analysis", Journal of Economic Surveys, 28(3), pp. $472-490$. https://doi.org/10.1111/joes.12035

Ulaşan, B. (2012) "Cross-Country Growth Empirics and Model Uncertainty: An Overview", Economics: The Open-Access, OpenAssessment E-Journal, 6, Article number: 2012-16. https://doi.org/10.5018/economics-ejournal.ja.2012-16

van der Ploeg, F., Venables, A. J. (2012) "Natural Resource Wealth: The Challenge of Managing a Windfall", Annual Review of Economics, 4, pp. 315-337. https://doi.org/10.1146\%2Fannurev-economics-080511-111003

Verter, N. (2017) "International Trade: The Position of Africa in Global Merchandise Trade", In: Ibrahim, M. J. (ed.) Emerging Issues in Economics and Development, IntechOpen, London, UK, pp. 65-89. https://doi.org/10.5772/intechopen.68897

\section{Appendix}

Table 5 Statistical properties of the series

\begin{tabular}{|c|c|c|c|c|c|}
\hline Series/Statistics & Mean & Standard deviation & Normality & Unit root-series in levels & Unit root-series in $1^{\text {st }}$ differences \\
\hline gdp & 8.07 & 0.88 & $22.80 * * *$ & -0.69 & $-4.83 * * *$ \\
\hline gdpe & 9.11 & 0.97 & $21.85 * * *$ & -1.00 & $-3.03 * * *$ \\
\hline gni & 8.05 & 0.88 & $21.82 * * *$ & -0.17 & $-2.99 * * *$ \\
\hline gcibr & 3.80 & 0.54 & $12.65 * * *$ & 2.97 & $-2.02 * *$ \\
\hline gciee & 3.48 & 0.42 & 0.45 & -1.19 & $-3.99 * * *$ \\
\hline gciif & 3.27 & 0.37 & 1.27 & -0.95 & $-4.35 * * *$ \\
\hline $\operatorname{gcf}$ & 3.14 & 0.41 & $506.47 * * *$ & 3.49 & $-5.86 * * *$ \\
\hline
\end{tabular}

Notes: gdp (gross domestic product in PPP per capita), gdpe (gross domestic product in PPP per person employed), gni (gross national income in PPP per capita), gcibr (subindex of basic requirements of the global competitiveness index), gciee (subindex of efficiency enhancers of the global competitiveness index), gciif (subindex of innovation and sophistication factors of the global competitiveness index), normality is tested by JarqueBera test under the null of normal distribution, unit root is tested by Breitung test under the null of unit root. All series expressed in logarithms. 
Table 6 Whole sample

\begin{tabular}{lccccc}
\hline Code & Country & Code & Country & Code & Country \\
\hline DZA & Algeria & LSO & Lesotho & TCD & Chad \\
BWA & Botswana & MRT & Mauritania & MDG & Madagascar \\
MUS & Mauritius & MAR & Morocco & MWI & Malawi \\
NAM & Namibia & NGA & Nigeria & MLI & Mali \\
ZAF & South Africa & TUN & Tunisia & MOZ & Mozambique \\
CMR & Cameroon & ZMB & Zambia & SEN & Senegal \\
CIV & Cote d'Ivoire & BEN & Benin & TAN & Tanzania \\
EGY & Egypt & BDI & Burundi & UGA & Uganda \\
GHA & Ghana & ETH & Ethiopia & ZWE & Zimbabwe \\
KEN & Kenya & GMB & Gambia & & \\
\hline
\end{tabular}

Table 7 Sub-Saharan countries

\begin{tabular}{|c|c|c|c|c|c|}
\hline Code & Country & Code & Country & Code & Country \\
\hline BWA & Botswana & MRT & Mauritania & MWI & Malawi \\
\hline MUS & Mauritius & NGA & Nigeria & MLI & Mali \\
\hline NAM & Namibia & ZMB & Zambia & MOZ & Mozambique \\
\hline ZAF & South Africa & BEN & Benin & SEN & Senegal \\
\hline CMR & Cameroon & BDI & Burundi & TAN & Tanzania \\
\hline CIV & Côte d'Ivoire & ETH & Ethiopia & UGA & Uganda \\
\hline GHA & Ghana & GMB & Gambia & ZWE & Zimbabwe \\
\hline KEN & Kenya & TCD & Chad & & \\
\hline LSO & Lesotho & MDG & Madagascar & & \\
\hline
\end{tabular}

Table 8 Middle income sub-Saharan countries

\begin{tabular}{|c|c|c|c|c|c|}
\hline Code & Country & Code & Country & Code & Country \\
\hline BWA & Botswana & CMR & Cameroon & LSO & Lesotho \\
\hline MUS & Mauritius & CIV & Côte d'Ivoire & MRT & Mauritania \\
\hline NAM & Namibia & GHA & Ghana & NGA & Nigeria \\
\hline ZAF & South Africa & KEN & Kenya & ZMB & Zambia \\
\hline
\end{tabular}

Table 9 Low income sub-Saharan countries

\begin{tabular}{|c|c|c|c|c|c|}
\hline Code & Country & Code & Country & Code & Country \\
\hline BEN & Benin & MDG & Madagascar & TAN & Tanzania \\
\hline BDI & Burundi & MWI & Malawi & UGA & Uganda \\
\hline ETH & Ethiopia & MLI & Mali & ZWE & Zimbabwe \\
\hline GMB & Gambia & $\mathrm{MOZ}$ & Mozambique & & \\
\hline $\mathrm{TCD}$ & Chad & SEN & Senegal & & \\
\hline
\end{tabular}

